\title{
Protocol
}

\section{Detecting Horseradish Peroxidase-Labeled Cells}

\author{
Scott J. Rodig
}

\begin{abstract}
A range of substrates is available for detection of cells labeled with horseradish peroxidase (HRP). Diaminobenzidine $(\mathrm{DAB})$ is the most commonly used substrate and one of the most sensitive. It yields an intense brown product that is insoluble in both water and alcohol. DAB staining is compatible with a wide range of common histological stains. DAB can be made more sensitive by adding metal salts such as cobalt or nickel to the substrate solution. The reaction product is slate gray to black, and the products are stable in both water and alcohol. DAB/metal staining is compatible with a wide range of common histological stains. Alternatively, chloronaphthol gives a blue-black product and aminoethylcarbazole (AEC) yields a red product. These substrates are less sensitive than DAB and the products are soluble in alcohol, but they can be used if the DAB reaction gives too high a background or if alternative product colors are required.
\end{abstract}

It is essential that you consult the appropriate Material Safety Data Sheets and your institution's Environmental Health and Safety Office for proper handling of equipment and hazardous materials used in this protocol.

\section{Reagents}

Cells labeled with horseradish peroxidase (HRP)-labeled antibodies $\mathrm{H}_{2} \mathrm{O}_{2}(3 \%)$

$\mathrm{H}_{2} \mathrm{O}_{2}$ is supplied as a $30 \%$ solution and should be stored at $4^{\circ} \mathrm{C}$. It will last $\sim 1 \mathrm{mo}$.

Sodium acetate (0.1 M, pH 5.2) (for detection using AEC)

Substrate for detection of HRP

Aminoethylcarbazole (AEC; 0.4\% in DMF) (see Steps 20-26)

Prepare a stock solution of AEC by dissolving $400 \mathrm{mg}$ of aminoethylcarbazole in $100 \mathrm{~mL}$ of n,n-dimethyl formamide (DMF).

Chloronaphthol (see Steps 14-19)

Prepare a stock solution of chloronaphthol by dissolving $0.3 \mathrm{~g}$ of chloronaphthol in $10 \mathrm{~mL}$ of absolute ethanol and storing at $-20^{\circ} \mathrm{C}$.

Diaminobenzidine (DAB) tetrahydrochloride (see Steps 1-6 and 7-13)

Nickel chloride or cobalt chloride $\left(0.3 \%\right.$, w/v) in $\mathrm{H}_{2} \mathrm{O}$ (see Steps 7-13)

Tris buffer ( $0.05 \mathrm{M}, \mathrm{pH} 7.6)$ (for detection using DAB or chloronaphthol)

Equipment

Whatman No. 1 filter paper

From the Antibodies collection, edited by Edward A. Greenfield.

(c) 2019 Cold Spring Harbor Laboratory Press

Cite this protocol as Cold Spring Harb Protoc; doi:10.1101/pdb.prot099713 
S.J. Rodig

\section{METHOD}

\section{Detecting HRP-Labeled Cells Using DAB}

Figure 1 shows the results of DAB-based chromogenic staining of formalin-fixed, paraffin-embedded human tonsil.

1. Dissolve $6 \mathrm{mg}$ of $\mathrm{DAB}$ in $10 \mathrm{~mL}$ of $0.05 \mathrm{~m}$ Tris buffer ( $\mathrm{pH} 7.6$ ).

2. Add $0.1 \mathrm{~mL}$ of $3 \% \mathrm{H}_{2} \mathrm{O}_{2}$.

3. If a precipitate appears, filter through Whatman No. 1 filter paper (or equivalent).

4. Apply to specimen and incubate for 1-20 min. Stop the reaction by washing in water.

5. (Optional) Counterstain if necessary (see Protocol: Counterstaining, Mounting, and Photographing Stained Cells [Rodig 2019]).

6. Mount in DPX (see Protocol: Counterstaining, Mounting, and Photographing Stained Cells [Rodig 2019]).

\section{Detecting HRP-Labeled Cells Using DAB and Metal Salts}

7. Dissolve $6 \mathrm{mg}$ of $\mathrm{DAB}$ in $9 \mathrm{~mL}$ of $0.05 \mathrm{~m}$ Tris buffer ( $\mathrm{pH}$ 7.6).

8. Add $1 \mathrm{~mL}$ of a $0.3 \%$ (w/v) stock solution of nickel chloride in $\mathrm{H}_{2} \mathrm{O}$ (the same amount of cobalt chloride can be used as an alternative).

9. Add $0.1 \mathrm{~mL}$ of a $3 \%$ solution of $\mathrm{H}_{2} \mathrm{O}_{2}$ in $\mathrm{H}_{2} \mathrm{O}$.

10. If a precipitate appears, filter through Whatman No. 1 filter paper (or equivalent).

11. Apply to specimen and incubate for 1-20 min at room temperature. Stop the reaction by washing in $\mathrm{H}_{2} \mathrm{O}$.
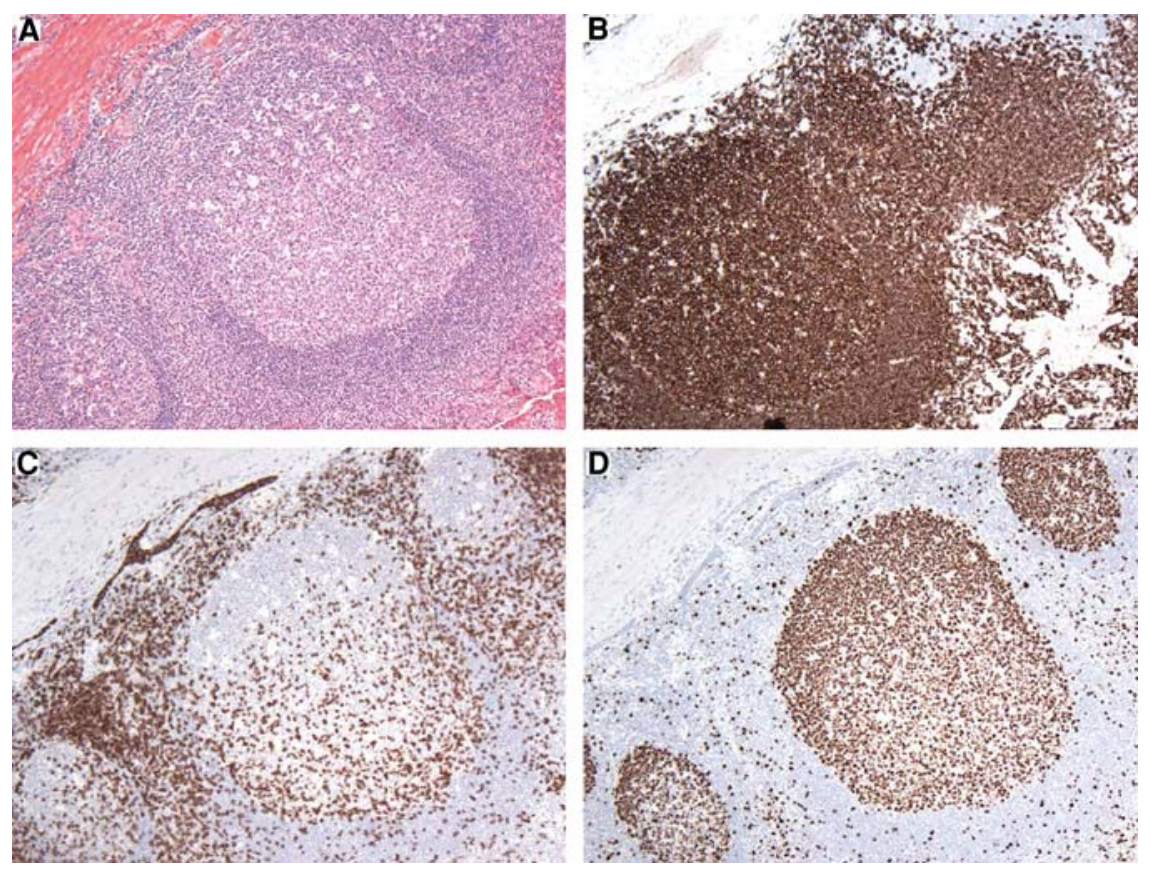

FIGURE 1. Human tonsil stains. Human tonsil stained with hematoxylin and eosin (A), anti-CD20 (B), anti-CD3 (C), and anti-Ki67 $(D)$. The images show reactive germinal centers that are rich in B cells $\left(\mathrm{CD} 20^{+}\right)$compared with T cells $\left(\mathrm{CD}^{+}\right)$and are sites of cellular proliferation $\left(\mathrm{Ki} 67^{+}\right)$. Brown coloration in $B-D$ indicates positive staining with antibody by IHC. Hematoxylin (but no eosin) was used as a counterstain in $B-D$. Photographed at $100 \times$ final magnification. 
12. (Optional) Counterstain if necessary (see Protocol: Counterstaining, Mounting, and Photographing Stained Cells [Rodig 2019]).

13. Mount in DPX (see Protocol: Counterstaining, Mounting, and Photographing Stained Cells [Rodig 2019]).

\section{Detecting HRP-Labeled Cells Using Chloronaphthol}

14. Add $100 \mu \mathrm{L}$ of chloronaphthol stock with stirring to $10 \mathrm{~mL}$ of $0.05 \mathrm{~m}$ Tris ( $\mathrm{pH} 7.6$ ).

15. Add $0.1 \mathrm{~mL}$ of $3 \% \mathrm{H}_{2} \mathrm{O}_{2}$ in $\mathrm{H}_{2} \mathrm{O}$.

16. Remove the white precipitate that forms by filtering through Whatman No. 1 filter paper (or equivalent).

17. Apply to specimen and incubate for $10-40 \mathrm{~min}$ at room temperature. Stop the reaction by washing in $\mathrm{H}_{2} \mathrm{O}$.

18. (Optional) Counterstain if necessary. Only aqueous stains can be used (see Protocol: Counterstaining, Mounting, and Photographing Stained Cells [Rodig 2019]).

19. Mount in Gelvatol or Mowiol (see Protocol: Counterstaining, Mounting, and Photographing Stained Cells [Rodig 2019]).

\section{Detecting HRP-Labeled Cells Using AEC}

20. Add $1.0 \mathrm{~mL}$ of the $0.4 \%$ AEC solution to $15 \mathrm{~mL}$ of $0.1 \mathrm{~m}$ sodium acetate buffer ( $\mathrm{pH} 5.2$ ) with stirring.

21. Add $0.15 \mathrm{~mL}$ of $3 \% \mathrm{H}_{2} \mathrm{O}_{2}$ in $\mathrm{H}_{2} \mathrm{O}$.

22. Filter through a Whatman No. 1 filter.

23. Apply the reagent to the cell specimen and incubate for 10-40 min at room temperature.

24. Stop the reaction by washing in $\mathrm{H}_{2} \mathrm{O}$.

25. (Optional) Counterstain if necessary. Only aqueous stains can be used (see Protocol: Counterstaining, Mounting, and Photographing Stained Cells [Rodig 2019]).

26. Mount in Gelvatol or Mowiol (see Protocol: Counterstaining, Mounting, and Photographing Stained Cells [Rodig 2019]).

The AEC product fades if oxidized. Take special care to avoid air bubbles upon mounting.

Tyramide signal amplification (TSA) is a proprietary technique used to increase the sensitivity of detecting low numbers of antibody-antigen complexes in tissues or cells (Zaidi et al. 2000; Krieg and Halbhuber 2010). The basis for activity is a time-dependent, HRP-catalyzed covalent attachment of labeled (biotin/fluorescent dye conjugated) molecules of tyramide to tyrosine residues on the nearby HRP-conjugated antibody or protein. The local deposition of the conjugate (biotin/fluorescent dye) is then detected by standard means (such as streptavidin-HRP/DAB or direct visualization of the fluorescent dye). Although such catalyzed amplification techniques can increase the sensitivity of detecting antibody-antigen complexes, they often come at the expense of increased background. A careful set of controls is necessary. 


\section{S.J. Rodig}

\section{REFERENCES}

Krieg R, Halbhuber KJ. 2010. Detection of endogenous and immuno-bound peroxidase-The status quo in histochemistry. Prog Histochem Cytochem 45: 81-139.

Rodig SJ. 2019. Counterstaining, mounting, and photographing stained cells. Cold Spring Harb Protoc doi: 10.1101/pdb.prot099770.
Zaidi AU, Enomoto H, Milbrandt J, Roth KA. 2000. Dual fluorescent in situ hybridization and immunohistochemical detection with tyramide signal amplification. J Histochem Cytochem 48: 1369-1375. 


\section{Detecting Horseradish Peroxidase-Labeled Cells}

Scott J. Rodig

Cold Spring Harb Protoc; doi: 10.1101/pdb.prot099713

\begin{tabular}{|c|c|}
\hline $\begin{array}{l}\text { Email Alerting } \\
\text { Service }\end{array}$ & Receive free email alerts when new articles cite this article - click here. \\
\hline $\begin{array}{l}\text { Subject } \\
\text { Categories }\end{array}$ & $\begin{array}{l}\text { Browse articles on similar topics from Cold Spring Harbor Protocols. } \\
\text { Cell Biology, general (1382 articles) } \\
\text { Cell Imaging (525 articles) } \\
\text { Imaging/Microscopy, general (579 articles) } \\
\text { Immunostaining (139 articles) } \\
\text { Immunostaining Cells (51 articles) } \\
\text { Immunostaining Tissues (84 articles) } \\
\text { Immunostaining, general (94 articles) } \\
\text { Labeling for Imaging (339 articles) } \\
\text { Visualization (524 articles) } \\
\text { Visualization, general (369 articles) }\end{array}$ \\
\hline
\end{tabular}

